\title{
HVMANITAS
}

\section{Meditação sobre a ruína das ruínas}

\section{Autor(es): $\quad$ Mantas, Vasco Gil}

Publicado por: Imprensa da Universidade de Coimbra

URL persistente:

URI:http://hdl.handle.net/10316.2/41852

DOI:

DOI:https://doi.org/10.14195/2183-1718_69_5

Accessed : $\quad$ 26-Apr-2023 11:41:06

A navegação consulta e descarregamento dos títulos inseridos nas Bibliotecas Digitais UC Digitalis, UC Pombalina e UC Impactum, pressupõem a aceitação plena e sem reservas dos Termos e Condições de Uso destas Bibliotecas Digitais, disponíveis em https://digitalis.uc.pt/pt-pt/termos.

Conforme exposto nos referidos Termos e Condições de Uso, o descarregamento de títulos de acesso restrito requer uma licença válida de autorização devendo o utilizador aceder ao(s) documento(s) a partir de um endereço de IP da instituição detentora da supramencionada licença.

Ao utilizador é apenas permitido o descarregamento para uso pessoal, pelo que o emprego do(s) título(s) descarregado(s) para outro fim, designadamente comercial, carece de autorização do respetivo autor ou editor da obra.

Na medida em que todas as obras da UC Digitalis se encontram protegidas pelo Código do Direito de Autor e Direitos Conexos e demais legislação aplicável, toda a cópia, parcial ou total, deste documento, nos casos em que é legalmente admitida, deverá conter ou fazer-se acompanhar por este aviso.

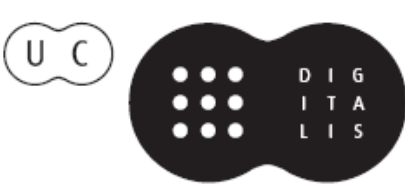




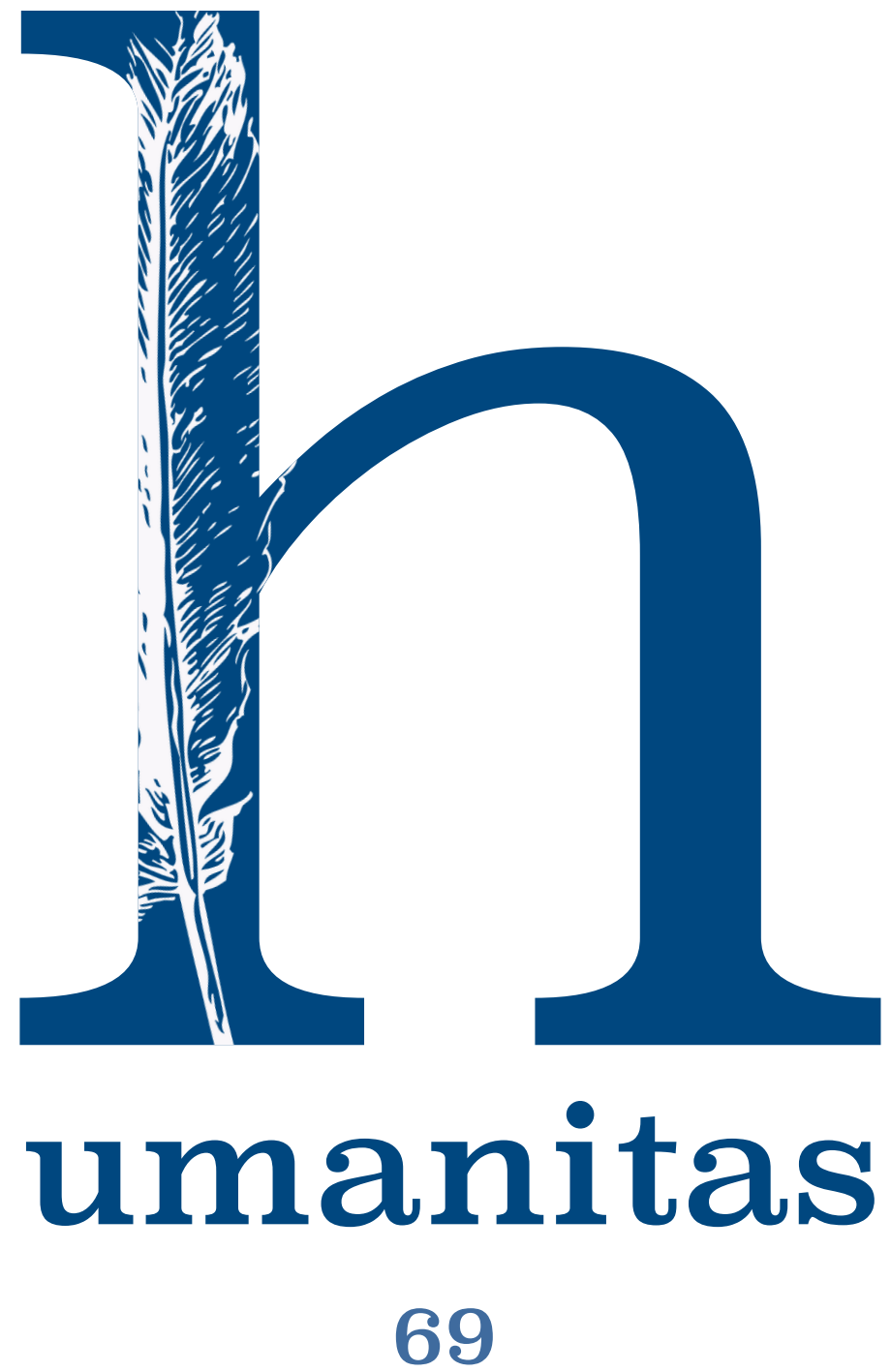

Imprensa da Universidade de Coimbra

Coimbra University Press 


\title{
MEDITAÇÃo SOBRE A RUÍNA DAS RUÍNAS
}

\section{MEDITATION UPON THE RUINS' RUIN}

\author{
Vasco Gil Mantas \\ Centro de Estudos Clássicos e Humanísticos da Universidade de Coimbra \\ vsmantas@gmail.com
}

Artigo recebido a 07-06-2016 e aprovado a 12-01-2017

\section{Resumo}

As ruínas da cidade de Palmira, importantes pela história e estado de conservação, sofreram recentemente atentados de que resultou a perda de alguns dos seus monumentos mais relevantes. O motivo subjacente às destruições corresponde à prática de eliminação do passado por razões ideológicas, o que obriga a reflectir sobre a evolução política do Próximo Oriente e a considerar as consequências previsíveis do caos regional desenvolvido nos últimos anos.

Palavras chave: Palmira, Império Romano, arquitectura, ideologia, radicalismo, geopolítica.

\section{Abtract}

The ruins of the city of Palmira, important for the history and state of preservation, have suffered recently from attacks that resulted in the loss of some of its most relevant monuments. The reason underlying the destruction corresponds to the practice of elimination of the past for ideological reasons, which forces to reflect on the political developments of the Middle East and to consider the predictable consequences of regional chaos developed in recent years.

Keywords: Palmyra, Roman Empire, architecture, ideology, radicalism, geopolitics.

Este é um texto que esperava nunca vir a escrever ${ }^{1}$, pois a matéria de que trata confirma o pessimismo com que assisti ao desenvolvimento da

1 Agradeço cordialmente ao Dr. Luís Madeira a preparação das imagens deste artigo e ao Dr. Óscar Nogueiro a cedência de algumas das fotos que o ilustram. 
história global nas últimas décadas e ao afastamento cada vez mais evidente, talvez irreversível, dos valores espirituais e cívicos sobre os quais se construiu a identidade do mundo civilizado, valores em grande parte herdados da Antiguidade Clássica ${ }^{2}$. Creio que a destruição de importantes testemunhos do mundo antigo no Iraque e na Síria, sem esquecer o saque sistemático de numerosos museus destes estados do Próximo Oriente, sublinhando naturalmente as barbaridades acontecidas em Palmira (Tadmor), marcam o ponto mais baixo de um processo de regressão, pela gravidade de que se revestem e pelo seu inegável valor simbólico. Centrarei as minhas reflexões em torno das ruínas de Palmira (Fig.1), cuja destruição, ainda que parcial, teria suscitado, anos atrás, uma reacção seguramente mais viva na opinião pública, motivadora, com toda a probabilidade, de uma acção que tardou em concretizar-se. Não me refiro a discursos ou a tomadas de posição retóricas, que pouco ocuparam a atenção dos meios de comunicação social, mas a operações no terreno, única forma de impedir a continuação da catástrofe, publicitada como se fosse mais um absurdo reality show ${ }^{3}$, idêntico a tantos com que nos embrutecem diariamente.

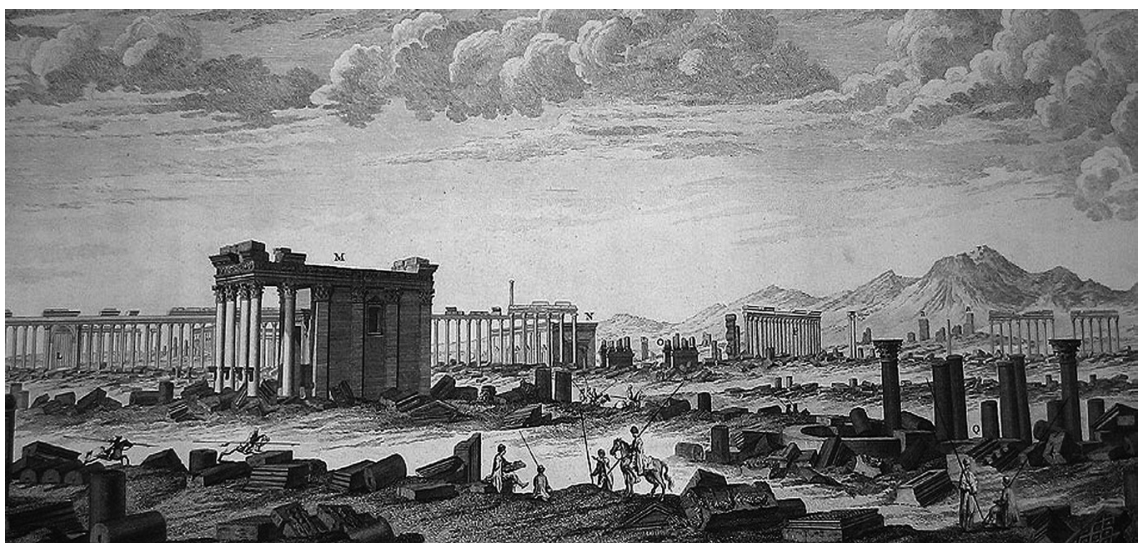

Figura 1 - As ruínas de Palmira em 1753, com o templo de Baal Shamin em primeiro plano (gravura de Robert Wood).

Sempre tive uma relação platónica com as ruínas de Palmira, e digo platónica porque nunca encontrei oportunidade de as visitar. A cidade do oásis tornou-se uma espécie de lugar especial onde se refugiam os sonhos e onde

Mantas 2012: 47-73.

3 Harmanşah 2015: 170-177. 
por vezes se procura abrigo, sabendo que nele nada nos pode atingir, uma espécie de utopia à qual conseguimos atribuir uma imagem física concreta, ainda que intemporal e ideal, desde logo livre de turistas. Por isso mesmo senti duramente os actos de destruição premeditada que ali aconteceram. Remonta ao início da década de 60 do século passado o meu primeiro contacto com a história das ruínas, antes vagamente entrevistas numa ou noutra fotografia, quando adquiri através de encomenda postal uma edição portuguesa da obra de Volney intitulada Les Ruines, ou Méditation sur les Révolutions des Empires, vulgarmente conhecida em Portugal como As Ruínas de Palmira 4 . Confesso que na altura esperava mais ruínas e menos filosofia política na obra, a qual reflecte de forma clara o ambiente cultural da Revolução Francesa, de cuja herança talvez estejamos a viver agora os momentos finais, embora não como os teóricos de um impossível fim da história planearam.

Não posso deixar de aconselhar a leitura de As Ruínas de Palmira, ou sua releitura, porque todas as grandes obras exigem esse esforço de reinterpretação escalonado no tempo, parecendo evidente que a leitura de O Principezinho aos dez ou doze anos, ou de Os Sete Pilares da Sabedoria aos quinze ou dezasseis anos, não provoca os mesmos sentimentos que as mesmas obras, lidas em plena maturidade, acordarão. Na verdade, trata-se de uma excelente obra da literatura francesa, a qual tanto nos enriqueceu antes da proliferação de escritores de supermercado, com grandes nomes e poucas ideias, destacando-se desde logo a evocativa e impressionante descrição das ruínas da cidade síria, da qual sou devedor, em grande parte, da elaboração do meu lugar imaginário, porque as ruínas são, antes de mais, repositórios do mito, e por isso são destruídas, e nem sempre da mesma forma ${ }^{5}$, como infelizmente se vai observando em muitos lugares turísticos do pós-modernismo.

Para quem ame a Antiguidade Clássica e o deserto, paradoxal museu de cidades mortas, mais rico que aquelas terras superpovoadas e plenas de riquezas supérfluas onde habitamos, essas páginas iniciais de Volney são inesquecíveis e sublinham a gravidade dos atentados que se abateram sobre Palmira e a certeza de que as sociedades têm características biológicas, como defenderam Spengler e Toynbee, muito depois de Ibn Khaldun o ter feito ${ }^{6}$.

\footnotetext{
Volney s/d.[1960].

Mantas 2008: 147-192.

Ibn Khaldun 1958.
}

Humanitas 69 (2017) 111-145 
Passamos a citar uma parte do capítulo inicial, onde Volney descreve a sua impressão das ruínas, não como arqueólogo, mas como homem sensível ao que é extraordinário:

Assim cheguei à povoação de Homs, sobre as margens do Orontes; e achando-me perto de Palmira, situada no deserto, resolvi reconhecer por mim mesmo os seus famosos monumentos: ao cabo de três dias de marcha nas solidões mais áridas, tendo atravessado um vale cheio de grutas e de sepulturas, observei repentinamente ao sair deste vale uma imensa planície com a cena mais assombrosa de ruinas colossais; era uma multidão inumerável de soberbas colunas direitas, que, como as alamedas dos nossos jardins, se estendiam a perder de vista em filas simétricas e formosas. Entre estas colunas havia grandes edificios, uns inteiros, outros meio destruidos. Por toda a parte estava o terreno coberto de cornijas, de capitéis, de fustes, de pilastras, tudo de mármore branco, e de um trabalho requintado. Depois de três quartos de hora de caminho sobre estas ruínas, entrei no recinto de um vasto edifício que foi antigamente um templo dedicado ao Sol. Admiti a hospitalidade de uns pobres camponeses árabes, que tinham estabelecido as suas choças sobre o pavimento do templo e resolvi deter-me ali algum tempo para observar atentamente a beleza de tantas e tão sumptuosas obras.

Todos os dias saía a visitar algum dos monumentos que cobriam a planície; e uma tarde em que, ocupado o meu espirito em sérias reflexões, me tinha adiantado até ao Vale dos Sepulcros, subi às alturas que o rodeiam e desde as quais se domina ao mesmo tempo a vista da totalidade das ruinas e a imensidade do deserto...Acabava de pôr-se o Sol, e uma zona arroxeada marcava ainda o seu curso no horizonte longínquo dos montes da Síria; a Lua cheia levantava-se por oriente, sobre um fundo azulado, nas margens planas do Eufrates?.

Esta impressionante descrição do sítio de Palmira, considerada por alguns como um dos pontos altos da prosa francesa do século XVIII, termina curiosamente com a referência ao Sol e à Lua, duas das divindades principais da cidade, Malakbel e Aglibol, associadas a Baal Shamin, a divindade celeste que completava a tríade da cidade ${ }^{8}$, de que se conhecem diversos baixos-relevos, alguns deles felizmente recolhidos em museus europeus (Fig.2). Estas divindades pertencem a um antiquíssimo fundo

\footnotetext{
Volney 1791: 2-3.

8 Teixidor 1979: 29-52.
} 
religioso semita de características astrais, difundido na região levantina síro-fenícia e que, entre outros locais de culto dotados de grandes santuários se destacam Palmira e Baalbek (Heliopolis), este no Líbano9 . Alguns destes santuários contribuíram, através do imaginário religioso neles cultivado, para inspirar conceitos sociopolíticos que encontraram forte expressão através das utopias solares que marcaram o mundo helenístico e romano, sobretudo nos séculos III e II a.C., passando da literatura e da filosofia ao campo das aplicações políticas, nem sempre com bons resultados ${ }^{10}$.

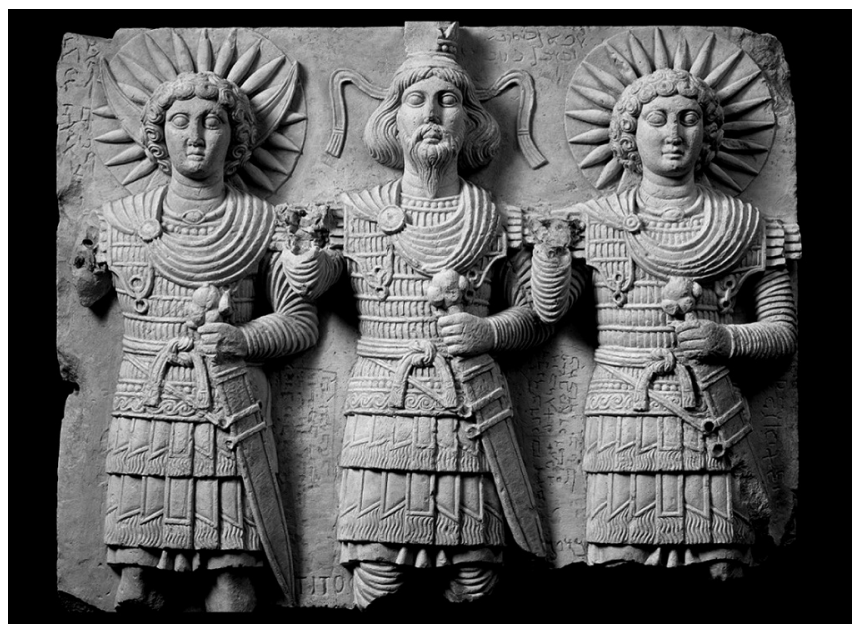

Figura 2 - Malakbel, Aglibol e Baal Shamin num baixo-relevo de Palmira (Museu do Louvre, Paris).

A descrição de Volney, forçosamente breve, pois o autor não desejou escrever um texto de intenção arqueológica, refere muito claramente alguns dos grandes monumentos de Palmira, como a grande colunata do Decumanus urbano, o templo de Bel e as torres funerárias, os últimos dos quais sofreram a acção destrutiva dos militantes do chamado "Estado Islâmico"11, continuando uma estratégia bem definida de terrorismo selectivo, bem conhecida nos manuais de guerra subversiva, na qual o terror é uma poderosa arma psicológica destinada a minar a estabilidade do opositor e a infundir o medo

Wiegand 1922-1923; Grant 1996: 33-35.

10 Ferguson 1975; Mantas 2003: 173-184.

11 Usarei no texto a sigla inglesa usual: ISIL. 
entre a população, esteja ela já controlada ou não. Permito-me chamar a atenção para a cronologia das destruições levadas a efeito em Palmira, a qual parece ter correspondido a uma atitude de expectativa quanto a possíveis reacções, não tanto das forças governamentais, a partir de Maio de 2015 ocupadas em defender principalmente o que se costumava designar nos tempos do mandato como la Syrie utile, mas por parte das potências que o poderiam ter feito na base de uma solicitação mais veemente da $\mathrm{ONU}$, cujas preocupações pareciam, nessa altura, francamente orientadas noutro sentido. É claro que não faltaram as tomadas de posição, mais ou menos abertas, de muitos intelectuais, mas, como é sabido, a toga permanece inerme perante as armas. Houve mesmo um chefe de Estado sul-americano que propôs negociações com o ISIL, como se tal fosse possível.

Vejamos a cronologia dos acontecimentos. A queda de Palmira aconteceu em 20 de Maio de 2015 e logo os meios de comunicação do ISIL informaram que não destruiriam na cidade mais que os monumentos ligados a cultos pagãos, apontando de imediato os alvos escolhidos, que incluíam, naturalmente, também relevos e esculturas. O primeiro edifício monumental a ser eliminado foi o pequeno templo de Baal Shamin, a 25 de Agosto, ou seja, mais de três meses após a queda da cidade na posse dos jihadistas. A 31 de Agosto seguiu-se a eliminação do principal monumento religioso de Palmira, o templo de Bel, que, pelas grandes dimensões, levantou problemas técnicos aos demolidores, possivelmente atrasando a sua destruição. No mesmo contexto, a 3 de Setembro, foram destruídas as principais torres funerárias, entre as quais a de Elahbel, grande construção da época de Trajano.

A destruição prosseguiu a 4 de Outubro, agora já alargada a outro tipo de monumento, o arco honorífico (Fig.3), dificilmente representativo de qualquer ideologia religiosa. Mais uma vez se verificou, entre um e outro acontecimento, um espaço temporal de um mês, durante o qual nada aconteceu para conseguir a protecção eficiente das ruínas da cidade, por essa altura ameaçadas de destruição total, como alertou Maamun Abdulkarim, director do Serviço de Antiguidades e Museus da Síria. Menos evidentes, prosseguiam os vandalismos no museu arqueológico, do qual poucas ou nenhumas peças foram evacuadas antes da queda da cidade, ao contrário do que foi divulgado. Como seria de esperar, a UNESCO considerou as destruições como "um crime intolerável", com o que todos estamos de acordo, pelo que parece, no mínimo, redundante tal afirmação. Mas como se reage perante crimes intoleráveis? 


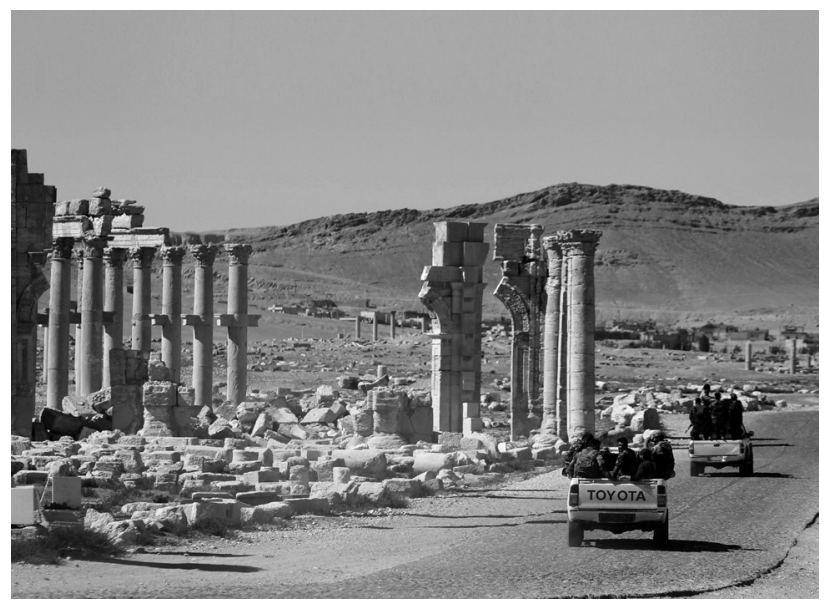

Figura 3 - Forças governamentais sírias passam junto ao arco honorífico destruído pelos jihadistas (foto Sana).

A eficiência dos demolidores, sobretudo no caso dos templos, é de sublinhar, o que confirma a presença de especialistas em demolição, provavelmente militares. Perante o que se vê no terreno, e as imagens de satélite já o haviam sugerido, o templo de Baal Shamin e o templo de Bel encontram-se totalmente destruídos, arrasados, o que levanta sérias dúvidas quanto a uma muito rapidamente propalada vontade de reconstruir os templos e o arco honorífico num prazo de cinco anos. Não creio que tal seja possível, com excepção do arco, de que grande parte da cantaria subsiste, permitindo uma anastilose eficiente. É certo que existe muita documentação sobre os templos, o que facilita uma reconstrução que, na maior parte consistirá em levantar uma cópia do edifício perdido, com recuperação de um ou outro elemento arquitectónico ${ }^{12}$. Talvez o reconhecimento das dificuldades em presença tenha levado a desviar a atenção para o arco honorífico, inclusive através das réplicas de uma pequena parte dele, em escala inferior à real, levantado em Londres ${ }^{13}$, pouco ou nada se divulgando sobre os restantes

12 Resta a questão, não respondida, de reconhecer quais os monumentos destruídos com que se identifica a população síria, talvez mais sensível a perdas representativas de períodos posteriores à Antiguidade.

13 Iniciativa do Institut for Digital Archaeology. Em algumas montagens fotográficas aparece erradamente o portal conservado do Templo de Bel. 
monumentos. A batalha de Palmira é agora, como foi sob a ocupação jihadista, uma questão de propaganda.

O contexto do Próximo Oriente pode ser confuso, complicado, no mínimo, para quem se habituou a uma história europeia de tipo linear, mentalmente bem organizada segundo quadros que, com frequência, se revelam insuficientes, quando não incómodos. Esta circunstância pode ser particularmente sensível em países como Portugal, onde a noção de Nacionalidade é antiga, fixadas as fronteiras por meados do século XIII, o que não deixa de contribuir para uma certa dificuldade em apreender outras histórias, cultural e politicamente mais instáveis. Se considerarmos também o peso dos lugares comuns e as generalizações abusivas, facilmente compreendemos o quão difícil se torna interpretar os acontecimentos. Não é aqui o lugar indicado para traçar a história do Próximo Oriente, mas devo recordar algumas das grandes linhas que a marcaram nos últimos cem anos. É costume atribuir a acção dos jihadistas a diferenças religiosas entre Xiitas e Sunitas, que tantas vezes têm levado a conflitos na região, mas a existência de um projecto político ambicioso, surgido da instabilidade que se estabeleceu após a intervenção contra o Iraque de Saddam Hussein, completada pela atabalhoada intromissão na Líbia, parece evidente.

Assumindo uma posição fundamentalista radical, de inspiração wahabita $^{14}$, excluindo qualquer diálogo com o que é considerado diferente, fora da norma, logo inimigo a destruir, a presente situação assume visos de guerra religiosa, indiscutivelmente, mas é igualmente uma guerra civil e palco de uma renovada Guerra Fria. Para complicar a questão, a intervenção directa ou velada de esta ou daquela potência a favor do regime sírio ou de alguma das múltiplas facções rebeldes, camuflando grandes interesses políticos e geoestratégicos, agravou uma situação de gestão complexa, atendendo ao ambiente político extremamente volátil do Próximo Oriente, mosaico de Estados mais ou menos artificiais nas fronteiras herdadas da dissolução do Império Otomano, nos quais as ditaduras têm normalmente constituído a alternativa possível à anarquia, desaparecido o imperialismo europeu. Religião e etnicidade são, portanto, o pano de fundo de Kriegsspiele ensaiados fora do cenário do conflito. $\mathrm{O}$ que se pressente por trás de tudo isto é o desenhar de um novo mapa regional, à custa de misérias sem conta e de destruições irreparáveis.

14 Kalisky 1968: 10-13. 
Para quem conhece alguma coisa da história do Próximo Oriente posterior ao desaparecimento da opressão otomana, o desenho territorial do ISIL parece inspirado no que ficou por cumprir das ilusões do grande Reino Árabe de T. E. Lawrence, se é que alguma vez houve intenção de criar esse grande Estado, que os acordos Sykes-Picot e o falhado tratado de Sèvres mostram nunca ter passado de uma ficção ${ }^{15}$. Na verdade, tudo o que se encontrava a norte da Arábia foi dividido por franceses e ingleses ${ }^{16}$, criando o mapa actual da região: Palestina, Jordânia, Iraque, Síria e Líbano. Uma figura menos conhecida, a extraordinária Gertrude Bell ${ }^{17}$, arqueóloga e conselheira de Winston Churchill na Conferência do Cairo, em 1921 (Fig.4), teve uma acção decisiva na formatação territorial do Iraque ${ }^{18}$, cometendo um erro de consequências gravíssimas ao incluir os Curdos no reino criado para Faisal, ou melhor, para servir os interesses britânicos nos recursos petrolíferos da região.

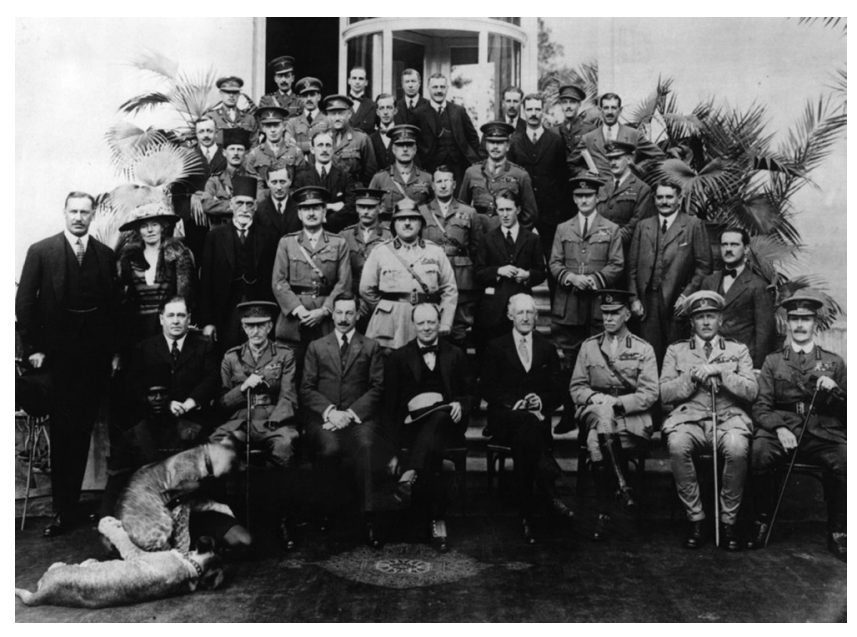

Figura 4 - Participantes na Conferência do Cairo. Distinguem-se Churchill, Allenby, Lawrence e Gertrude Bell (foto UKG).

Não se tratando de uma geografia fantástica, onde ecoa alguma coisa das velhas fronteiras orientais romanas ${ }^{19}$, não é menos verdade tratar-se

\footnotetext{
15 Fromkin 1989: 286-288; Barr 2011.

16 Satia 2008: 3-19.

17 Winstone 2004.

18 Lukitz 2006: 107-210.

19 Kennedy e Riley 2004: 4-48.
} 
de criações muito artificiais, ausentes do imaginário de grande parte das populações, sobretudo numa época em que a circulação de notícias e o estilo de vida fora dos centros urbanos permaneciam tradicionalmente imóveis. A escritora e também arqueóloga Agatha Christie, que conheceu bem o tempo heróico das escavações na Síria e no Iraque, deixou-nos uma imagem clara dessa sociedade bloqueada:

A moeda oficial do país é o franco francês, mas nesta região o mejidi turco usou-se tanto tempo que para os habitantes conservadores nenhuma outra é aceitável. Os bazares transacionam nesta moeda, embora os bancos não. Os nossos homens recusam-se terminantemente a receber noutra moeda que não seja o mejidi $i^{20}$.

Esta inércia de ordem política, que talvez implicasse também a recusa do novo amo estrangeiro, não deixou de ser aproveitada pelo vizinho turco, pois o desejo de recuperar territórios permaneceu de forma latente, o que pode explicar algumas ambiguidades no quadro da actual crise síria. Recordamos um passo em que Ferreira de Castro refere um episódio vivido e que reflecte esta tensão, quando as publicações de belas imagens turcas que o escritor transportava foram objecto de suspeitosa observação na alfândega síria, não fosse o autor de $A$ Volta ao Mundo tratar-se de um agente pró-turco ${ }^{21}$. As independências após a Segunda Guerra Mundial mantiveram as fronteiras do período anterior, agravando-se a situação com a permanente hostilidade entre o Estado de Israel, criado em 1948, e os países da região, onde se desenvolveu um nacionalismo pan-arabista, cujo mentor será o paladino do Socialismo Árabe, o presidente egípcio Gamal Abdel Nasser ${ }^{22}$.

Todavia, as teias da Guerra Fria, o fracasso do mito da unidade árabe e diversos conflitos perdidos face a Israel não contribuíram para acalmar a situação. Falhada a tentativa socialista, cuja inspiração, fosse como fosse, era de modelo europeu, o desvio das populações para formas radicais de base religiosa era uma inevitabilidade, que as intervenções ocidentais na região e o estrondoso falhanço das quimeras da Primavera Árabe catapultaram para o primeiro plano das piores realidades do século XXI. Por tudo isto, que não posso aprofundar como seria conveniente, não devemos admirar-nos que os radicais destruam, por razões ideológicas ou como tal anunciadas, o que

20 Christie 2010: 126.

21 Ferreira de Castro 1942: 149.

22 Kalisky 1968: 170-233. 
muitas vezes não só é considerado ímpio pelos jihadistas, como é declarado valioso pelos que eles consideram inimigos. Devemos, pois, esperar novas destruições e ataques a sítios turísticos particularmente importantes, como aconteceu, por exemplo, em 2015 no Museu do Bardo, em Túnis. Parece que o problema, posto desta forma, ultrapassa a questão síria, mas não é assim. Vivemos uma era global, ainda que muitas vezes sejam os mais acérrimos defensores desta realidade a esquecerem o seu significado e os muitos efeitos perversos que encerra.

Voltemos, porém, a Palmira, sem que seja possível esquecer o bacanal de destruições, ligadas ou não a acções militares, de que a Síria tem sido palco, perpetradas não apenas pelos militantes do ISIL, parte das quais têm incidido sobre o acervo dos museus ou sobre sítios arqueológicos, nomeadamente através de "escavações" destinadas a encontrar objectos destinados ao mercado negro das antiguidades, que floresce sobretudo na Turquia. Esta prática é muito anterior à guerra $\mathrm{civil}^{23}$, mas ganhou incontrolado desenvolvimento desde que a ordem, ou pelo menos a ordem policial, foi substituída pela insegurança e brutal imoralidade generalizadas. Parece-me estranho, no mínimo, que se insista na reconstrução de Palmira de uma forma que quase sugere displicência em relação aos outros sítios arqueológicos destruídos ou em vias de destruição, como Apameia, cujos mosaicos aparecem à venda na Turquia, ou Mari, em cujas ruínas as imagens de satélite permitem identificar mais de um milhar de cavas na área do palácio. Estamos perante uma imensa, irremediável, marcante catástrofe.

Transcrevi, no início, a impressão do Conde de Volney à vista da cidade arruinada. Antes de traçar algumas considerações sobre a história de Palmira e sobre os seus monumentos destruídos ou danificados, quero recordar o que escreveu Agatha Christie, nos anos 30 do século passado, sobre o perturbador efeito da visão das ruínas:

Depois, após sete horas de calor e monotonia e de um mundo de solidão - Palmira! Penso que é esse o encanto de Palmira - a sua beleza esbelta de tom creme, que se eleva fantasticamente no meio da areia quente. É encantadora, fantástica e incrivel, com toda a teatral improbabilidade de um sonho. Pátios e templos e colunas em ruínas... Nunca fui capaz de concluir o que penso realmente de Palmira. Para mim tem sempre o mesmo carácter de sonho da primeira vez que a $v^{24}$.

23 Sournia e Sournia 1966: 146-149.

24 Christie 2010: 53. 
Com que sonharemos, agora que a noiva do deserto foi violada?

A importância da cidade resultou da sua localização privilegiada sobre as grandes rotas das caravanas, oásis com nascentes perenes, a principal das quais era a de Efqa, que secou em 1994, nascente sob protecção de outra das grandes divindades locais, Yarhibol ${ }^{25}$. Continua a discussão sobre a origem do nome da cidade, que na época romana pode relacionar-se sem dificuldade com os palmares existentes na sua periferia. Não vou desenvolver um sumário sobre a história de Palmira, sobre a qual não faltam publicações acessíveis, reservando a atenção para o seu período romano, o de maior desenvolvimento e ao qual pertencem os grandes monumentos palmirenses. Além de uma posição relevante como placa de comunicações servindo a longuíssima rota da seda, em direcção aos portos do Golfo Pérsico ou através do seu percurso terrestre setentrional, ou a rota das especiarias, através do território nabateu até ao Mar Vermelho, a cidade situava-se estrategicamente numa zona de charneira entre o Império Romano e o Império Persa, o que lhe conferia particular importância como guarda avançada do mundo helenístico-romano. Como é natural, os frequentes conflitos entre os dois impérios não deixaram de ter consequências sensíveis em Palmira.

A cidade entrou na órbita romana em 64 a. C., por acção de Pompeio, após a vitória deste sobre os Selêucidas, mantendo-se independente. Apesar de uma tentativa falhada de Marco António, no âmbito da sua desastrosa política oriental ${ }^{26}$, Palmira só viria a ser anexada no principado de Tibério, mantendo as instituições políticas locais, uma espécie de conselho tribal ocidentalizado, a funcionar. Estação de caravanas, a cidade vai transformar-se ao longo do século I numa grande urbe, ao mesmo tempo quer se melhorava a rede viária que a servia, por razões militares e comerciais, dinâmica que se desenvolve nos primeiros tempos do século seguinte ${ }^{27}$. A anexação do Reino Nabateu por Trajano contribuiu fortemente para a riqueza da cidade ao longo do século II, pois permitiu um maior controlo sobre os fluxos comerciais vindos do Mar Vermelho e da Arábia, o que parece reflectir-se em alterações na navegação comercial naquele mar, com nítida quebra de movimento em Berenike, no Egipto ${ }^{28}$.

\footnotetext{
25 Smith II 2013: 64-66.

26 Elton 1996: 90; Roddaz 2000: 879-888.

27 Smith II 2013: 122, 185.

28 Sidebotham 2011: 206-258.
} 
No século II, Palmira, cujo território se estendia por mais de 150 quilómetros entre os limites noroeste e sudoeste, de acordo com os dois padrões demarcatórios que se conhecem ${ }^{29}$, era uma cidade muito rica, como os seus monumentos públicos e a sua invulgar arte funerária privada demonstram. O essencial da população era amorita, aramaica e árabe, mas não faltavam elementos gregos, latinos e judaicos, assim como colónias de palmirenses eram conhecidas em muito centros comerciais dentro e fora do Império Romano. A cidade constituía, pois, um excelente exemplo de uma sociedade formalmente greco-romana, helenística, se desejarmos, com um sólido fundo oriental, próprio de uma metrópole comercial cosmopolita. Declarada cidade livre por Adriano, em 129, foi elevada à condição de colónia cerca de 213, por Caracala, ao mesmo tempo que a sua importância militar aumentava no cenário das guerras com a Pérsia, contando com uma guarnição permanente a partir de 206.

A militarização de Palmira cresceu com a ameaça representada pelos Sassânidas, o que levou ao advento de uma nova estrutura política, de tipo real e militar, como sugere o título de Exarchos ostentado por Lúcio Septímio Odenato cerca de 250, que usara um pouco antes, o título indígena de Ras (senhor, chefe militar). A derrota de Valeriano teve consequências nas transformações políticas em Palmira, reforçando a posição de Odenato, que conseguiu travar o perigo persa, derrotando Shapur em 260 e depois os usurpadores surgidos no Oriente. Seguiram-se novas vitórias que levaram Galieno a atribuir-lhe o título de Corrector Totius Orientis, o que legalizou o seu controlo sobre todo o Oriente entre a Anatólia e a Arábia, elevando Palmira à condição de Estado aliado ${ }^{30}$. O factor militar na sociedade palmirense, que parece predominante no século III, reflecte-se também na presença de tropas auxiliares recrutadas na região e presentes noutros locais do Império, nomeadamente no Egipto, empregues na segurança das comunicações entre o Mar Vermelho e o Nilo ${ }^{31}$. A tónica militar na cultura da cidade é, todavia, anterior, como demonstra o facto das divindades da tríade de Palmira serem representadas com traje militar, acusando uma significativa romanização progressiva do mesmo $^{32}$.

29 Encontrados em Kirbet El Bilaas e em Kasr al-Hayr al-Gharbi.

30 Young 2003: 159.

31 Schwartz 1976: 139-151; Edwell 2008: 62.

32 Perfeitamente visível nos baixos-relevos conservados no Museu do Louvre e no Museu de Lião, por exemplo. 
A conclusão lógica desta evolução, depois do assassínio de Odenato em 267, foi a eclosão do chamado Império de Palmira, sob o governo de Júlia Aurélia Zenóbia, segunda esposa de Odenato, pretextando tutelar o filho menor, Vabalato. Os historiadores dividem-se na apreciação dos cerca de 12 anos que durou a governação de grande parte do Oriente, incluindo o Egipto, por Zenóbia. Uma parte dos especialistas interpreta a secessão, que só se confirma depois de 271, quando Zenóbia (Bat-Zabbai) adopta o título de Augusta (Fig.5), circunstância que, conjugada com a conquista da Arábia e do Egipto implicava uma ruptura definitiva com Roma ${ }^{33}$. Inicialmente, todavia, não houve quebra da política de dependência formal seguida por Odenato. Creio que este problema deve ter em conta a situação caótica do Império Romano na época, roído por usurpações e divisões territoriais que, vistas no Oriente, só podiam facilitar a tarefa dos rivais iranianos, convidando-os a uma desforra.
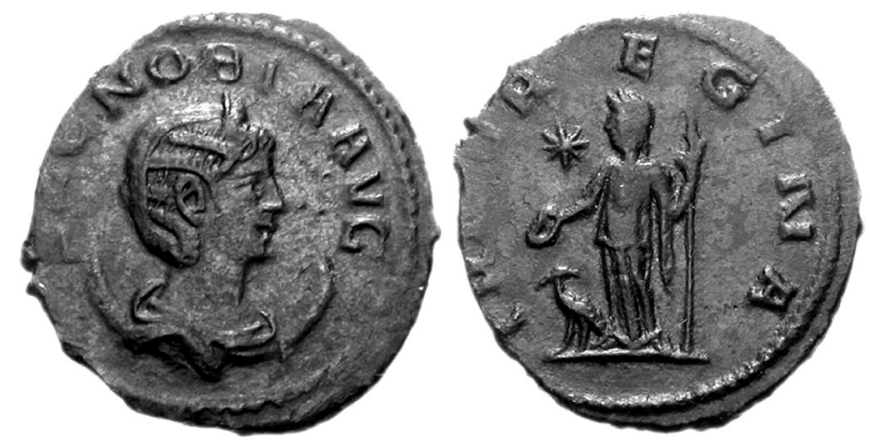

Figura 5 - Antoniano de Zenóbia, com o título de Augusta e uma muito romana Iuno Regina no reverso (RIC V 2: 3122).

Por outro lado, a situação geral nas províncias orientais do Império era diferente da decadência que se ia afirmando no Ocidente, pois tinham sido largamente beneficiadas no século III pelos imperadores da dinastia Severa. Não esqueçamos que a comemoração do milenário de Roma, em 248, foi presidida por Filipe, o Árabe, imperador oriundo da região de Bostra, no sul da Síria ${ }^{34}$, o que confirma a inegável importância atingida pelo Oriente e pelos seus efectivos militares na

Smith II 2013: 179; Ball 2014: 74-86.

34 Prickartz 1995: 129-153; Ball 2014: 417-418. 
política imperial, sinal claro da transferência do centro de gravidade político para Oriente, concluído meio século depois com a promoção de Constantinopla a capital imperial. A atitude de Zenóbia compreende-se facilmente e pode ser interpretada como uma atitude de autodefesa perante os perigos que ameaçavam os territórios que foi englobando nos domínios de Palmira perante a incapacidade ou impossibilidade de intervenção de Roma ${ }^{35}$.

Assim, a acção de Zenóbia não pode nem deve comparar-se com a de Cleópatra, pois no essencial, criando um grande espaço oriental sob a sua tutela, a rainha de Palmira procurava, mais que afirmar uma posição político-cultural oposta ao que Roma representava, salvaguardar uma realidade resultante de três séculos de presença romana. Seja como for, a figura de Zenóbia parece votada a interpretações românticas ou politicamente marcadas pela pretendida resistência indígena ao domínio romano $^{36}$, normalmente difícil de provar, com uma ou outra excepção pontual. O facto de Zenóbia ter sido promovida como símbolo nacionalista pelo regime sírio pode ter pesado nas destruições que se abateram sobre Palmira ${ }^{37}$, uma vez que para o ISIL o nacionalismo árabe não tem qualquer sentido.

Talvez estejamos, afinal, perante um caso precoce e relativamente bem-sucedido da emergência de poderes regionais com uma base étnica e territorial mais ou menos coerente, como aconteceu na mesma altura com o chamado Império das Gálias. No fundo, o que a Tetrarquia iria conceber uma dúzia de anos depois conheceu aqui uma espécie de antecedente, tanto mais que Zenóbia tomou o Egipto a um usurpador e de início reconheceu Aureliano como imperador. O território que Diocleciano vai governar directamente como Augusto corresponde, quase por completo, ao espaço controlado por Zenóbia, o que demonstra a existência de um embrião de unidade, ainda que marcada por grandes diferenças culturais, às quais uma forte estrutura helenístico-romana garantia uma viabilidade funcional.

A aventura de Zenóbia, que talvez tenha preservado o Oriente romano face à ameaça iraniana, terminou mal, pois Aureliano não aceitou a situação e entrou em conflito com a rainha, cujas forças vencidas

35 Millar 1993: 159-173; Southern 2008: 83-130.

36 MacMullen 1992.

37 Sahner 2014: 153.

Humanitas 69 (2017) 111-145 
em várias batalhas não conseguiram evitar o ataque a Palmira. Como o pedido de rendição foi repelido, Aureliano investiu a cidade, após ter capturado Zenóbia em fuga para o lado sassânida do Eufrates. A rainha foi levada prisioneira para Roma e daqui para diante instala-se a dúvida quanto à sua sorte, que alguns historiadores pretendem ter sido morte natural durante o exílio em Tivoli ${ }^{38}$. A população de Palmira revoltou-se pouco depois e a cidade, que fora poupada, foi atacada, saqueada e sofreu larga destruição ${ }^{39}$ transformando-se num grande posto militar, onde Diocleciano viria a construir um campo legionário permanente. Com a derrota de Zenóbia começou o declínio irreversível de Palmira, cuja função urbana enfraquecida foi substituída por uma função militar activa na Strata Diocletiana, a grande via militar na rectaguarda do limes oriental, entre Sura e Bostra, onde ligava com a Via Nova Traiana ${ }^{40}$.

Palmira não foi abandonada e manteve alguma população civil, embora a área urbana tenha sido muito reduzida. Os acontecimentos tiveram, porém, impacte sobre a vida quotidiana dos habitantes, desaparecida a opulenta classe mercantil, os quais se afastam gradualmente dos cultos tradicionais ou lhes atribuem identificações próprias de um fenómeno de interpretatio, como uma dedicatória a Zeus proveniente do templo de Baal Shamin sugere ${ }^{41}$. No período bizantino a cidade, cedo cristianizada, teve uma nova muralha e houve construção de alguns edifícios públicos, como igrejas, ainda que parte delas tivesse sido instalada em antigos templos. Em 634 a cidade, quase reduzida ao campo de Diocleciano, foi tomada pelos muçulmanos no cenário da sua ofensiva relâmpago contra as forças do imperador Heráclio, iniciando-se um novo período da sua história, quase sempre agitado e que terminou com a transformação do que fora uma metrópole no deserto numa paupérrima aldeia, deslocada pela administração francesa em 1932 para permitir os trabalhos arqueológicos (Fig.6).

Southern 2008: 156-164.

Ball 2014: 80-81

Lewin 2011: 233-264; Silver 2015: 279-285.

Dunant 1971: 43-44. 


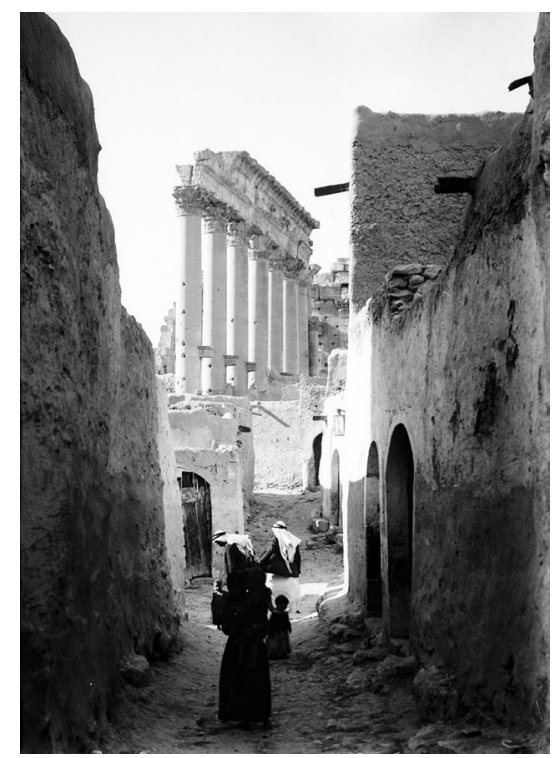

Figura 6 - A aldeia de Tadmor e o templo de Bel no início do século XX. Dois mundos distintos e opostos.

As primeiras escavações científicas efectuadas em Palmira tiveram lugar em 1902 e em 1917, sob orientação dos alemães Otto Puchstein e Theodor Wiegand ${ }^{42}$, continuadas pelo francês Henri Seyrig a partir de 1929. Com algumas interrupções episódicas, nomeadamente durante a década de 40 do século passado, as escavações arqueológicas e o estudo e publicação dos achados provenientes da cidade continuou a bom ritmo ${ }^{43}$, ainda que grande parte da área urbana, muito vasta, continue por escavar, pouco se conhecendo das zonas habitacionais, uma vez que foi dada prioridade à zona monumental e aos grandes edifícios públicos, religiosos e profanos, assim como a parte das necrópoles. Esta circunstância pode ter sido positiva para a conservação de numerosos restos, ainda desconhecidos, como os mosaicos que certamente existem em grande número e de elevada qualidade nessa zona da cidade pouco escavada.

O urbanismo da cidade, tal como se conhece, pertence ao período de pleno desenvolvimento, entre os séculos II e III. Embora de nítida influência

42 Theodor Wiegand, que se notabilizou-se também como pioneiro da fotografia aérea aplicada à arqueologia, foi distinguido com a Adlerschild, importante galardão alemão, em 1934 .

43 Adnan e al-Assad 2000. 
helenística, a planta de Palmira não corresponde ao modelo hipodâmico normal, menos ainda ao modelo ortogonal romano, embora se lhe atribua um Decumanus com um traçado sinuoso, com quebras de direcção disfarçadas por um tetrápilo e por um arco honorífico, e um Kardo, situado no limite oriental da cidade, continuando a estrada vinda de Damasco. O forum ou ágora comercial ocupa uma posição excêntrica, no limite urbano, junto à muralha construída por Zenóbia e reforçada por Justiniano, embora perto do teatro. Não houve, portanto, um planeamento homogéneo, orientando-se os eixos principais de forma a comunicarem com os templos principais, o que parece ser nítido no caso do Decumanus e do santuário de Bel (Fig.7), que terá levado ao desvio do uádi al-Kubur para sul. Já se avançou a hipótese de a rua ter sido traçada de forma a sugerir o movimento aparente do Sol, desde o templo de Bel até ao templo de Alate, na extremidade oeste da cidade, o que creio pouco credível. Por outro lado, as insulae a noroeste da cidade, longas e estreitas, definem um padrão regular de ruas paralelas per strigas, sugerindo um plano integrado ${ }^{44}$. A área no interior da muralha, cujo perímetro ronda os seis quilómetros, era inicialmente mais vasta, indicando uma população elevada, ainda que, como quase sempre acontece, dificil de calcular.

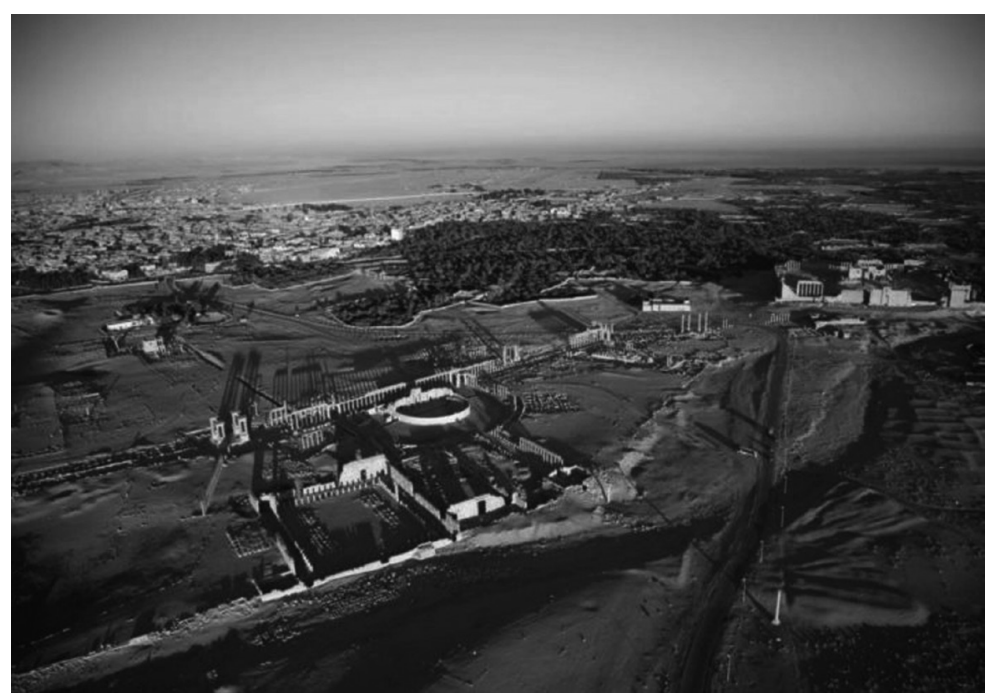

Figura 7 - Vista parcial das ruínas de Palmira, identificando-se alguns dos seus monumentos principais.

44 Wheeler 1964: 60; Van Berchem 1976: 165-173. 
As colunatas das ruas principais e os pórticos dos grandes edifícios públicos mostram uma característica não muito vulgar fora do Oriente, ostentando mísulas nos fustes, as quais outrora suportavam estátuas de bronze, tal como acontecia também noutras cidades da região, entre as quais Dura Europus, Hatra e Gerasa ${ }^{45}$. A existência de arruamentos e de monumentos envolvidos por pórticos não carece de explicação numa cidade construída em pleno deserto. A rua que se identifica com o Kardo parece ter sido construída, ou pelo menos a sua colunata, entre o governo de Trajano e o de Adriano. O grande arruamento em direcção ao templo de Bel terá sido lançado ou monumentalizado, de acordo com testemunhos epigráficos, entre 158 e 225, com maior actividade constructiva nos tempos de Septímio Severo e de Caracala, talvez em relação com a atribuição do título, honorífico, de colónia.

Como acontecia com os viajantes que se aventuravam no deserto séculos atrás para visitar as ruínas, a chegada a Palmira devia causar um profunda impressão aos viajantes da época romana, ao depararem após a monotonia áspera do deserto, com uma metrópole de imponentes santuários, ruas movimentadas, comércio rico e activo artesanato, sem esquecer a evidente exuberância de uma elite política e económica, em grande parte relacionada com as actividades mercantis centradas na cidade. Um testemunho eloquente dessa elite, desaparecidos outros, são os relevos funerários palmirenses ${ }^{46}$, sobretudo dos séculos II e III, representando homens vestidos à ocidental e mulheres, não raramente belas, ostentando uma pesada parure orientalizante, que me recorda a Dama de Elche. Assumindo poses altivas ou melancolicamente pensativas (Fig.8), invocando o invisível para além do horizonte, estas damas de Palmira, sem atingirem a perfeição, demasiada para alguns, da escultura clássica ${ }^{47}$, reflectem o poderio da cidade e, simultaneamente, o quanto há de efémero no que se pensa adquirido e imperturbável. As senhoras de Palmira, cujas figuras foram também alvo de destruição à martelada, merecem-nos um pensamento de respeito, não de pena, pois foram os homens de hoje que falharam na sua defesa.

45 Wheeler 1964: 60-61.

46 Parlasca 1976:33-43; Strong 1995: 166-169.

47 Wheeler 1964: 160-163.

Humanitas 69 (2017) 111-145 


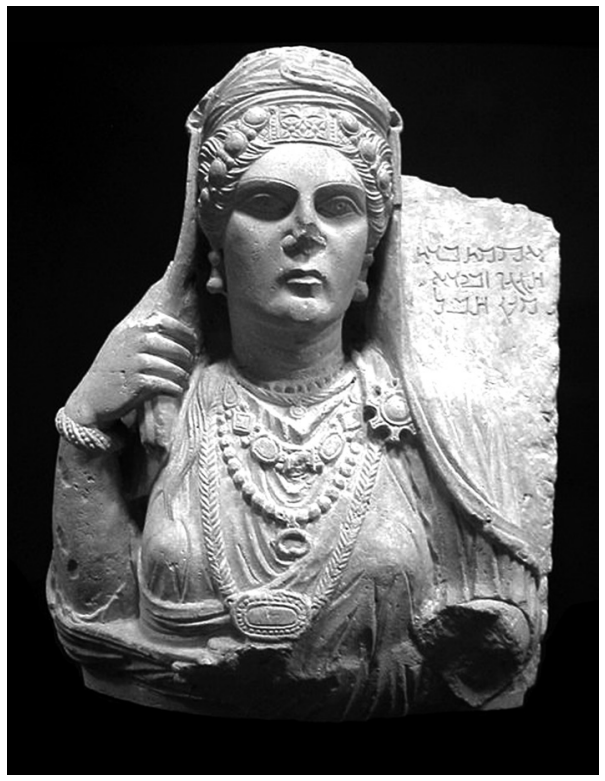

Figura 8 -Estela funerária com o retrato de Aqmat, filha de Hagagu (Museu Britânico, Londres).

Vejamos então quais os principais monumentos destruídos ou severamente danificados pelos jihadistas, sem esquecer que a guerra civil já havia causado estragos no património arqueológico de Palmira ${ }^{48}$. Um dos monumentos rapidamente destruído foi o Leão de Alate, animal sagrado desta deusa de origem árabe ${ }^{49}$, que se situava frente ao museu, grande peça de escultura representando o leão protegendo um antílope do deserto (oryx). Felizmente, embora bastante danificado, parece possível a sua recuperação, o que já não se pode dizer dos relevos que se encontravam no museu, mesmo os relevos funerários, cujas figuras tiveram as faces esboroadas ou foram em parte pilhados, como sugerem os espaços vazios nas paredes do museu. Alate foi interpretada pelos greco-romanos como sendo a deusa Ártemis ou Diana, a antiquíssima Senhora dos Animais do Levante mediterrânico ${ }^{50}$. O templo desta deusa parece ter sido construído no século I, embora a

48 Ali 2013: 42-53; Pigeaud 2015: 4-7.

49 Teixidor 1979: 53-61.

50 Moscati 1963: 240-241; Tozza 2015: 59-81. 
epigrafia correspondente sugira uma renovação na primeira metade do século II e uma evolução progressivo do fenómeno interpretativo.

Outra vítima jihadista foi o templo de Baal Shamin, que no período bizantino foi transformado em igreja e depois em mesquita. Este templo encontrava-se muito bem conservado e o tecto da cela possuía uma exuberante decoração. Era um edifício tetrastilo, pseudoperíptero, de ordem coríntia, com as paredes exteriores da cela dotadas de pilastras e com uma janela, elemento pouco usual na arquitectura religiosa romana ocidental mas que ocorre noutros monumentos de Palmira, nomeadamente no templo de Bel. As colunas ostentavam as usuais mísulas para sustentar as desaparecidas estátuas, provavelmente em bronze (Fig.9). O templo de Baal Shamin, o Senhor dos Céus de origem síria, normalmente interpretado como Zeus ou Júpiter, foi reconstruído por um notável local em 131, para comemorar a visita do imperador Adriano à cidade, mas o Temenos do santuário é anterior $^{51}$. O templo de Tébessa (Theveste), na Argélia ${ }^{52}$, seguramente posterior, recorda pelo estilo, dimensões e elementos orientalizantes nele identificados, a arquitectura deste templo de Palmira.

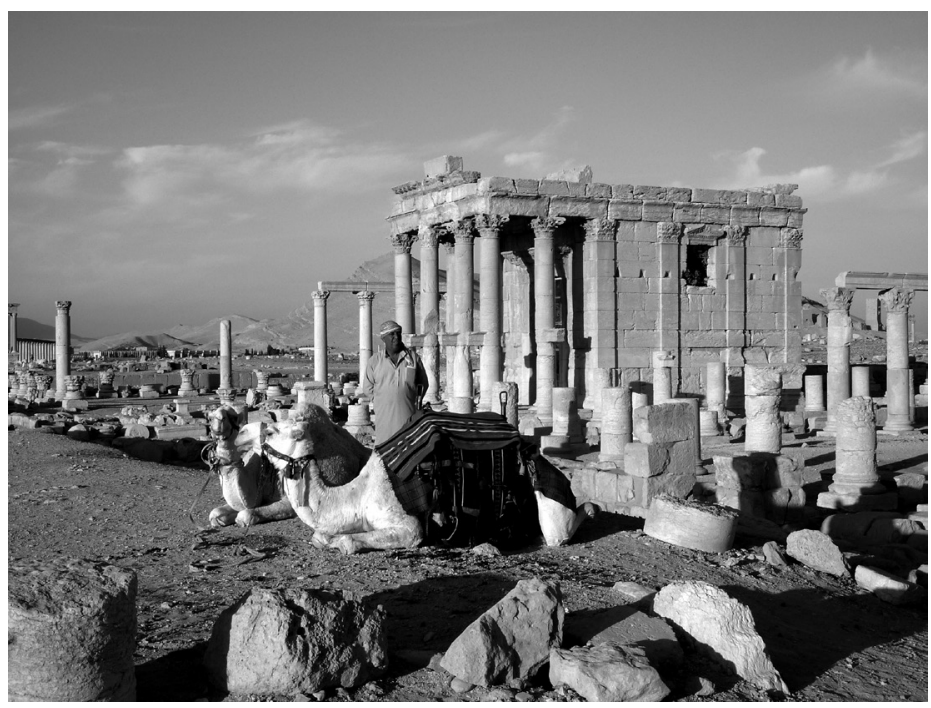

Figura 9 - Os camelos turísticos e o templo de Baal Shamin, em 2010 (foto Óscar Nogueiro).

$51 \quad$ Gollard e Vicari 1969.

52 Dareggi 2000; Robertson 1992: 217-218. 
A principal vítima da barbárie em Palmira foi o grande santuário de Bel, cujo templo constituía um extraordinário exemplar do sincretismo arquitectónico no mundo romano, aliando elementos semitas, gregos e romanos. O templo levantava-se no centro de um grande pátio porticado, de planta quadrangular, com 205 metros de lado. A entrada fazia-se através de um propileu, que em tempos possuiu seis portas de bronze, a que se acedia por uma escadaria monumental lembrando a do santuário de Baalbek ${ }^{53}$. O templo propriamente dito elevava-se sobre um estilóbato e era de ordem coríntia, com os capitéis recobertos por bronze dourado, há muito desaparecido. A entrada fazia-se através de uma escadaria de suave declive, não axializada, pela fachada maior do lado poente. A cobertura era em terraço, com quatro torreões, tudo encimado por almenas ${ }^{54}$, como no templo de Baal Shamin.

Era um edifício octastilo e períptero, dotada de frontões triangulares que apenas serviam para conferir um aspecto clássico às fachadas anterior e posterior. O interior da cela, iluminado por janelas e muito decorado, contava com duas exedras contrapostas. O templo, embora dedicado em 32, no principado de Tibério $^{55}$, sofreu posteriores modificações, sobretudo na época de Adriano (Fig.10). A análise da planta sugere semelhanças com o templo de Vénus e Roma, na capital imperial, templo em que não hesito em identificar traços próprios da arquitectura síria, fortemente presente no Império na época de Trajano com as obras de Apolodoro de Damasco ${ }^{56}$, o que talvez explique a origem do conflito que teria oposto o arquitecto ao imperador Adriano ${ }^{57}$. Como era habitual, o altar sacrificial ficava na esplanada, rodeada em três dos lados por uma dupla colunata, frente à fachada principal. Sobre este formidável monumento escreveu Mortimer Wheeler:

The whole aspect of the place is, to the classically minded, more then a little bizarre and even a trifle sinister. The transmutation of Roman architecture by alien traditions and usages could scarcely be carried further ${ }^{58}$.

\footnotetext{
53 Donald 1966: 122-128; Barton 1989: 84-86.

54 Picard 1965: 163-167.

55 Millar 1993: 323; Gros 1996: 162-164.

56 Picard 1959: 182-183; Abdulkarim e Calcani 2003: 25-64.

57 Dião Cássio H.R. 69. 27.

58 Wheeler 1964: 64.
} 


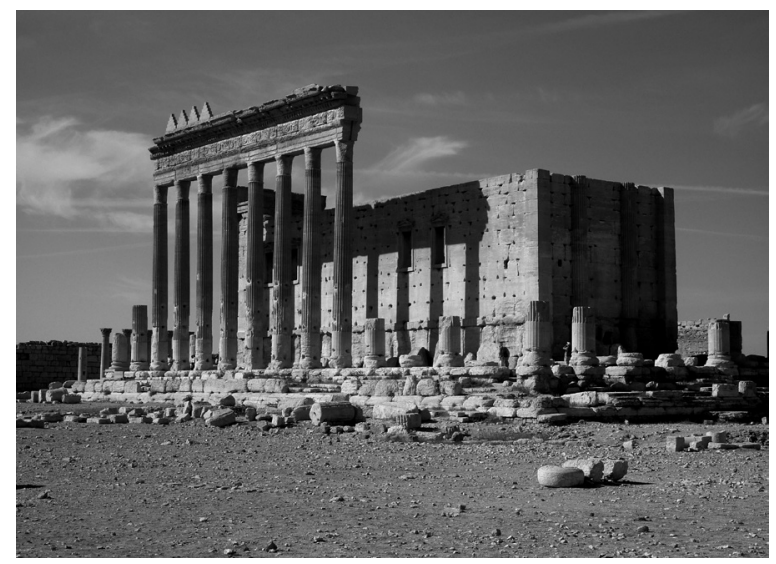

Figura 10 - Colunata e fachada oriental do templo de Bel, em 2010 (foto Óscar Nogueiro)

Este edifício tem um lugar especial na história da arquitectura do Império, a qual exige com frequência, sobretudo no Oriente, uma razoável flexibilidade interpretativa. O desconforto sentido por Wheeler, para quem a possibilidade de vir a acontecer uma tragédia em Palmira pareceria algo impensável, soa vagamente premonitória do que, afinal, sucedeu. A destruição foi eficiente, apenas sobrevivendo o portal adossada à colunata da fachada (Fig.11). Na verdade, parece-me praticamente impossível qualquer restauro coerente do templo. Assim, um monumento que não tinha há muito qualquer significado religioso e que apenas podia recordar um passado de prosperidade vivido na região, foi destruído por quem pretende apagar a história, por contraste demasiadamente incómoda para os seus propósitos.

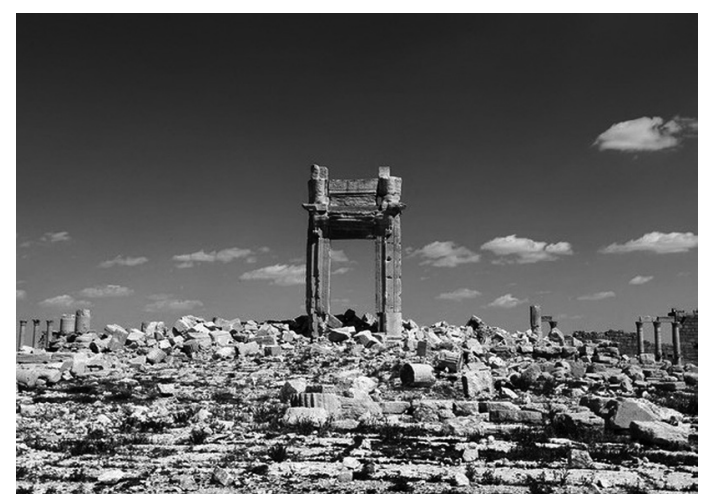

Figura 11 - Estado actual do templo de Bel, destruído em 2015 (foto Sana). 
O arco honorífico de Palmira, elevado por Caracala, mereceu também a atenção dos jihadistas, ainda que as suas motivações neste caso sejam menos claras. O arco, de três aberturas, faz a ligação entre dois tramos com orientação diferente do chamado Decumanus. É um monumento de elegante arquitectura e que possui uma característica interessante, na linha dos trompe l'oeil vulgares na arquitectura romana. Com efeito, para disfarçar a mudança de direcção da rua, o arco tem planta triangular, acomodada à visão de quem se aproxima dele de um ou de outro lado. Esta solução encontra-se, por exemplo, no forum novo de Leptis Magna, terminado em 216, onde a ligação entre a praça e a basílica se faz recorrendo ao mesmo artifício ${ }^{59}$. Aliás, esta preocupação de axialização é um ponto forte da arquitectura romana, visível, por exemplo, tanto nos fora imperiais em Roma como no forum de Pompeios, onde se criou uma falsa regularidade através de uma colunata escondendo a maior parte das fachadas. Apesar de bastante maltratado pelos explosivos, o arco de Palmira pode ser reconstruído, razão pela qual, talvez, se lhe dê tanta atenção, quando os templos são praticamente ignorados nas mensagens destinadas à opinião pública.

Um monumento pouco prejudicado foi o teatro, cuja datação não colhe o acordo dos arqueólogos, oscilando entre os séculos I e III, o que parece indicar diversas renovações. O edifício, que provavelmente não teve a cavea terminada, é pequeno e denota, no desenho da orchestra, alguma influência dos teatros helenísticos. Situa-se numa zona importante da cidade, inserido numa praça semicircular rodeada por um pórtico, perto do forum, cujas funções era sobretudo comerciais. Todavia, o teatro ficou para sempre manchado pelos assassinatos, a que se chamam execuções, que ali tiveram lugar. Passará muito tempo antes que esta sombra se atenue e não foi certamente o concerto que ali teve lugar pouco tempo depois da libertação de Palmira pelas forças governamentais e seus aliados que apagará o terror vivido no que até há pouco era um lugar de cultura ${ }^{60}$, concerto que proclama o falhanço total do que, em tempos, se chamou o Ocidente.

Outro alvo de destruição organizada, de impossível recuperação, foi o extraordinário conjunto de grandes torres funerárias do Vale dos

59 Wheeler 1964: 62, 52-56.

60 No teatro tinha lugar até ao início da guerra civil o Festival de Palmira de Cultura e Artes, semelhante ao Festival de Jerash e ao Festival de Baalbek. 
Túmulos (Fig.12), na periferia da cidade, por onde Volney passou antes de entrar nas ruínas. Seis dessas torres, entre as quais as de Elahbel, Jamlishu, Atenatan e Khitot, as mais imponentes, foram destruídas com explosivos, aniquiladas. Eram excelentes construções, com vários andares, que funcionavam como grandes mausoléus ou columbários familiares dos notáveis de Palmira ${ }^{61}$, construídas entre o século I e o século II, a última datada de 128. Pertencem, portanto, a um período de grande desenvolvimento económico da cidade, que se reflectia no autoelogio dos notáveis. Muito ornadas no interior e com os nichos funerários enobrecidos por retratos dos defuntos em baixo-relevo, conservavam, como no caso do elaborado tecto da Torre de Elahbel, a pintura que enriquecia a decoração, constituindo um dos raros exemplos conservados da policromia arquitectónica antiga (Fig.13).

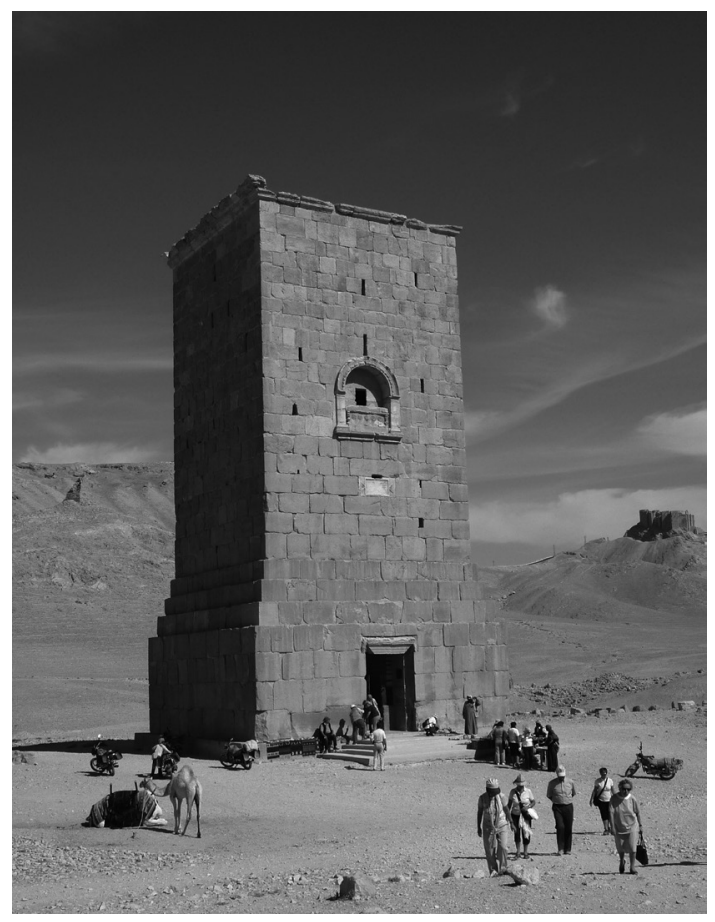

Figura 12 - A torre funerária de Elahbel (103 d.C.), em 2010 (foto Óscar Nogueiro).

$61 \quad$ Picard 1965: 168-170. 


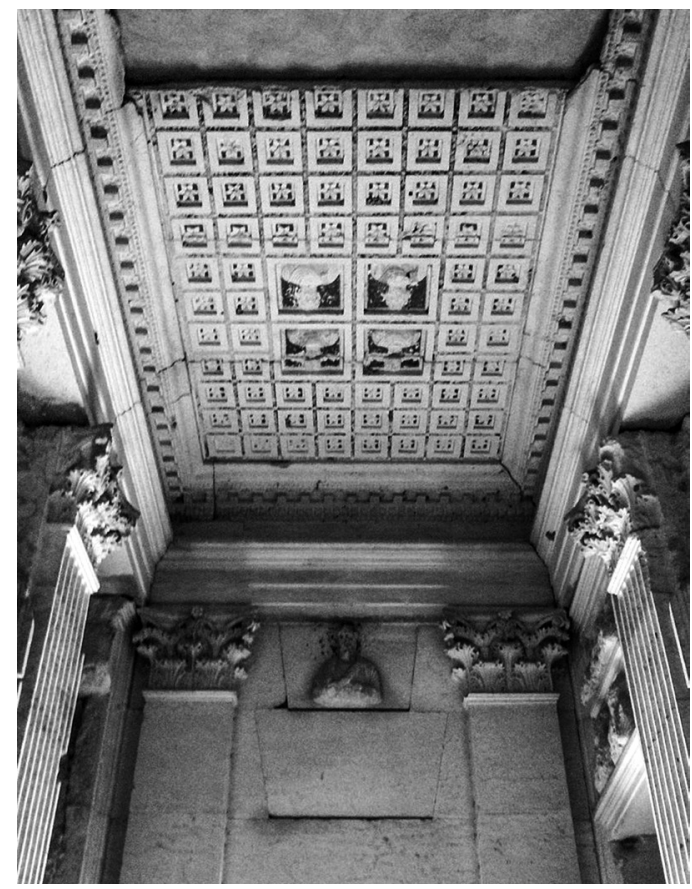

Figura 13 - Interior da torre de Elahbel, com tecto policromado (foto Óscar Nogueiro).

Outros monumentos da cidade, embora não visados directamente por actos de destruição, sofreram prejuízos nos combates que se travaram em Palmira e também devido ao abandono e falta de manutenção. Quanto ao importante Museu Arqueológico, frente ao qual se levantava o Leão de Alate, o seu acervo sofreu prejuízos irreparáveis, pois foi pilhado e as peças a que foi atribuída alguma conotação religiosa destruídas ou desfiguradas, como aconteceu com numerosos monumentos funerários que incluíam figuras humanas. Grande parte destes baixos-relevos, que constituíam uma impressionante galeria de retratos, está perdida definitivamente. Uma apertada vigilância sobre os mercados de antiguidades, a ser possível, não deixará de identificar peças provenientes deste e de outros museus, em certos casos completamente saqueados. Talvez neste aspecto a intervenção internacional se revele mais importante e premente que a propalada reconstrução das ruínas de Palmira em cinco anos. Creio que, também neste caso, nos mantemos no círculo das ilusões. Se foi possível reconstruir a Ponte de Mostar, já os Budas de Bamiyan, permaneceram, naturalmente, irrecuperáveis. Como 
poderá ser reconstruído o templo de Bel, sem que tenhamos, afinal, apenas uma cópia imperfeita, um pasticho para eventuais turistas, desprovido da auréola cativante que envolve as grandes ruínas?

A destruição de monumentos ao longo dos tempos é, infelizmente, uma realidade presente em todos os conflitos, militares ou ideológicos. Muitas destas destruições resultaram apenas da estupidez ou da ignorância de quem as perpetrou, enquanto outras resultaram dos azares da guerra, justificadas por operações militares. A demolição de arcos na romana Ponte de Alcântara pertence a essa categoria ${ }^{62}$, infelizmente responsável por enormes e irreparáveis destruições, por vezes resultantes do desconhecimento da situação no cenário operacional, como no triste caso do Mosteiro de Monte Cassino ${ }^{63}$. Muito diferentes são os atentados cometidos de forma deliberada contra bens de interesse histórico e cultural, ainda por vezes disfarçados por razões de ordem militar, como sucedeu em 1945 com a aniquilação da cidade alemã de Dresda. Não acontece assim quando o motivo é abertamente ideológico, usando aqui a expressão no seu sentido mais lato, situação em que tudo, ou quase tudo, é possível.

As destruições motivadas por razões de ordem ideológica são determinadas pelo valor simbólico do alvo. Como é evidente, o seu número e ubiquidade impedem a elaboração de um levantamento, mesmo sumário. Os múltiplos conflitos que se desenvolveram no século passado e as suas sequelas no presente facultam exemplos copiosos e dramáticos, sem necessidade de recuar muito no tempo. Indicarei apenas um exemplo e o seu contrário, que me parece representar bem este tipo de situações, a destruição da cidade alemã de Königsberg, capital histórica da velha Prússia, e a demolição do Palast der Republik, em Berlim, após a queda do muro. Ambos os casos, e poderia acrescentar muitos mais, reflectem uma vontade evidente de eliminar os testemunhos físicos do passado, por razões políticas.

Königsberg foi largamente destruída pelos bombardeamentos da RAF em Agosto de 1944, sofrendo depois os efeitos de um violento cerco soviético em 1945, nos últimos meses da guerra. O centro histórico ficou devastado e nos anos que se seguiram ao final do conflito as autoridades soviéticas decidiram apagar os traços de uma cidade considerada símbolo de uma sociedade militarista e reaccionária, procedendo à demolição generalizada das ruínas históricas subsistentes. Assim se perdeu o Castelo,

62 Blanco Freijeiro 1975: 46-51.

63 Bauer 1969: 158-162.

Humanitas 69 (2017) 111-145 
com todo o centro histórico, à excepção da Catedral, mantida em ruínas até aos inícios dos anos 90. Entre as muitas igrejas arruinadas e depois demolidas conta-se aquela onde se encontrava o túmulo do almirante português Marquês de $\mathrm{Nisa}^{64}$. A intenção clara foi a da russificação da cidade, agora denominada Kaliningrado, suprimida a memória do passado prussiano, o que foi completado pela eliminação ou expulsão dos residentes alemães sobreviventes $^{65}$. O caso de Königsberg, que tem na supressão em Berlim do Palast der Republik uma atitude idêntica, mas de sinal contrário, pois se demoliu o edifício mais emblemático da RDA na cidade, aliás construído no local do arrasado palácio real, mostra até que ponto se pode ir em termos de obliteração da memória e, simultaneamente, na criação de falsos passados e de improváveis futuros.

As razões de ordem religiosa não têm sido menos nocivas à preservação de monumentos. Presentes em todas as épocas, esperaríamos não continuar a assistir a tragédias semelhantes no século actual, o que já se revelou um sonho falhado. A conflitualidade entre as três Religiões do Livro, semitas na origem, muito tem contribuído para este lastimável historial. No Império Romano encontramos uma legislação abundante, por vezes contraditória, progressivamente endurecida com a estabilização do Estado cristão, a partir dos finais do século IV. À margem da lei, ou com a conivência das autoridades ${ }^{66}$, não faltaram turbas fanáticas ocupadas na destruição de santuários pagãos e também de sinagogas, sobretudo a partir de 380, quando Teodósio estabelece o Cristianismo como religião oficial pelo Edicto de Tessalonica. De nada valeu a famosa intervenção de Libânio junto do imperador, em defesa dos monumentos pagãos ${ }^{67}$, irremediavelmente condenados.

Os rescritos imperiais reflectem bem o evoluir da situação. Constâncio e Constante ainda determinavam, em 346, que os templos fora das muralhas de Roma fossem conservados, abrindo também uma excepção para aqueles que estivessem tradicionalmente relacionados com os jogos públicos ${ }^{68}$. O discurso é muito diferente no tempo do desgraçado principado de Honório. Eis o que consta num rescrito de 399 :

${ }^{64}$ O almirante morreu durante uma missão diplomática, em 1802, tendo sido provavelmente sepultado na Propsteikirche, igreja católica.

65 Davies 2015: 449-455.

66 Blánquez Pérez 2014: 48-63.

67 Libânio Or. 30.

68 C.Th. 16.10. 13 
Os mesmos Augustos (Honório e Arcádio) a Eutiquiano, Prefeito do Pretório. Se ainda houver alguns templos nos distritos rurais, eles devem ser demolidos sem distúrbios e sem tumultos. Pois, quando eles estiverem destruídos e removidos, a base material de toda a superstição será destruída ${ }^{69}$.

Uma constituição de Honório e Teodósio II, datada de 407 é ainda mais clara, determinando a destruição das imagens e dos altares e a transferência para uso público dos templos sobreviventes. Ordena ainda que os proprietários rurais sejam compelidos a destruir os templos existentes nas suas terras ${ }^{70}$, pondo assim em causa os últimos grandes redutos do paganismo. Palmira conta também com um lugar nesta história de intolerância, pois sabemos que o templo de Alate foi destruído em 385-386 por ordem do Prefeito do Oriente, Materno Cinégio ${ }^{71}$.

Este gosto pela destruição volta a encontrar-se no período bizantino no contexto de um conflito que marcou a Igreja Oriental, a iconoclastia, com todos os problemas políticos e sociais que envolveram este movimento fundamentalista ${ }^{72}$. Não esqueçamos, todavia, o que sucedeu na Europa em períodos posteriores, sobretudo no quadro do estabelecimento da Reforma $^{73}$. Por outro lado, uma grande despreocupação com a reutilização de materiais, sobretudo de materiais nobres, foi particularmente nociva para os grandes monumentos situados em zonas muito urbanizadas, em contexto de afirmação de poder, como sucedeu em Roma, desde a construção do Arco de Constantino até às grandes edificações renascentistas ${ }^{74}$. No mundo islamizado o fenómeno também não foi desconhecido, embora a desertificação de vastas zonas do Oriente e do Norte de África tenham em parte salvaguardado durante séculos ruínas incomparáveis, como as de Palmira, sem qualquer utilidade para populações nómadas. Mas houve, naturalmente, muitos estragos, por razões utilitárias ${ }^{75}$, religiosas ou por simples estupidez, como terá acontecido com a demolição da monumental

\footnotetext{
69 C.Th. 16. 10. 16

70 Const.Sirm. 12.

71 Stoneman 1994: 190.

72 Grabar 2000.

73 Hayman 2015.

74 Moatti 1989: 15-21, 45-52, 130-143.

75 Muitos materiais arquitectónicos foram exportados para serem reutilizados noutras construções, como sucedeu com as ruínas de Cartago, de que há colunas na Mesquita da Córdova.
} 
estátua de Hércules / Melqart, em Cádis ${ }^{76}$. Não é o caso, seguramente, da vaga de destruições protagonizada pelos jihadistas.

Os desastres que aconteceram no Iraque e na Síria foram anunciados tempos atrás, sem que tivessem suscitado a atenção que mereciam. A emergência de um jihadismo extremamente agressivo e motivado, com grande facilidade de recrutamento, local e internacional, era uma questão de tempo e o tipo de actuação a seguir já tinha sido ensaiado no Afeganistão. Quer isto dizer que o Mediterrâneo se aproxima de novo da imagem de fronteira defendida na célebre tese de Pirenne ${ }^{77}$, com a agravante de que não é intransponível e que a perplexidade domina entre os responsáveis europeus quanto à estratégia a seguir $^{78}$. Deixo este assunto para outra oportunidade e outro local, voltando ao problema da salvaguarda da herança clássica. Não duvidemos que, erodido interiormente e combatido do exterior, o conjunto de valores culturais e morais que a constituem estejam abertamente em perigo. Pode perguntar-se se eles se coadunam com o quotidiano, ou seja, se são funcionais no mundo contemporâneo. Só posso responder afirmativamente, pois de outra forma a nossa civilização cairá, como já caíram outras ${ }^{79}$.

Concentrando-me apenas no património arqueológico do período clássico é evidente que a ameaça de destruições idênticas às de Palmira é real e abrange países em torno da bacia mediterrânica que conservam grande parte do que melhor nos ficou da herança material greco-latina. Alguns desses países já se encontram a braços com actividade jihadista muito activa, caso da Líbia. A contaminação, segundo o princípio da mancha de azeite não é difícil e a situação pode vir a revelar-se, novamente, desastrosa. Países como o Egipto, a Jordânia e a Tunísia recorrem a esse património como meio de angariar divisas através do turismo, circunstância que tem contribuído muito positivamente para a sua conservação e estudo, o que o torna um objectivo prioritário. Como reagiremos se Leptis Magna ou Petra forem destruídas? Voltaremos a expedir lamentos e a declarar que se trata de crimes contra a humanidade? Ou será que o sistema das ditaduras cientificas, enunciado por Huxley ${ }^{80}$, já se estabeleceu para que consideremos normal o que ontem era inaceitável?

\footnotetext{
76 Almagro-Gorbea 2013: 159-202.

77 Pirenne, 1939: 147-185.

78 Bawer 2010: 233-361.

79 Sournia e Sournia 1966: 174-176.

80 Huxley s/d: 227-245.
} 
Está na hora de terminar, e não o quero fazer sem voltar a Palmira e à memória de Zenóbia, da qual a excêntrica Lady Hester Stanhope nos disse ter sido coroada sucessora pelos beduínos, sob o arco honorífico da cidade (Fig.14), como rainha do deserto ${ }^{81}$, durante a sua aventurosa viagem às ruínas, em 1813. Voltamos, assim, ao mundo dos símbolos e das quimeras românticas, que não me fazem esquecer as lágrimas que Zenóbia choraria se visse de novo a cidade de Palmira, lágrimas impossíveis, deixadas para alguns de nós. Italo Calvino na sua obra As Cidades Invisíveis inclui uma imaginária cidade com o nome da rainha ${ }^{82}$, cidade que o autor não diz se deve ser incluída entre as felizes ou infelizes, o que pode ser extensivo a Palmira:

Não é nestas duas espécies que faz sentido dividir a cidade, mas noutras duas: as que continuam através dos anos e das mutações a dar forma aos desejos e aquelas em que os desejos ou conseguem aniquilar a cidade ou são eles aniquilados ${ }^{83}$.

Opto firmemente pela primeira possibilidade ${ }^{84}$.

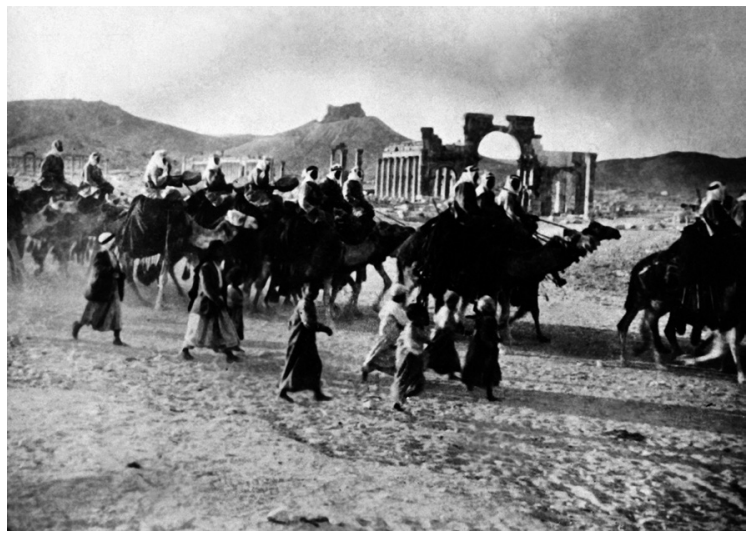

Figura 14 - Um grupo supletivo meharista atravessa as ruínas da cidade nos anos 20 do século passado.

81 Morató 2006: 105-107.

82 Existe sobre o Eufrates uma cidade fundada por Zenóbia em 266, com o seu nome, mas sem qualquer relação com o texto de Italo Calvino.

83 Calvino 2010: 37-38.

84 Não terminaram, como parecia, as vicissitudes de Palmira, reocupada em 11 de Dezembro de 2016 pelos militantes do ISIL. Este acontecimento mostra a precariedade da situação militar síria e como eram infundados os projectos de reconstrução, tão rápida quanto pomposamente anunciados, o que apenas valorizou as ruínas como objectivo simbólico a destruir. Quem as defende? Quem as quer defender? 


\section{Bibliografia}

Fontes:

C.Th. $=$ Const.Sirm. (1952), The Theodosian Code and Novels and the Sirmondian Constitutions (trad. C. Pharr). Princeton.

Dião Cássio (1925), Roman History (trad. E. Cary), VIII. Londres.

Libânio (1977), Libanius. Selected Works (trad. A. F. Norman), II. Cambridge. $\mathrm{RIC}=$ Roman Imperial Coinage. Londres.

Estudos:

Abdulkarim, M. e Calcani, G. (2003), Appolodoro e la Colonna Traiana a Damasco. Roma.

Adnan, B. e al-Assad, K. (2000), Palmyra. History, Monuments and Museum. Damasco.

Ali, Ch. (2013), "Syrie, un patrimoine en otage et sans protection", Archéologia 515: 42-53.

Almagro-Gorbea, M. (2013), “La 'Tumba de Melqart' del Herákleion de Gadir”, Madrider Mitteilungen 54: 51-202.

Ball, W. (2014), Rome in the East. The Transformation of an Empire. Londres Nova Iorque.

Barton, I. M. (1989), "Religious Buildings”, in I. M. Barton (ed.), Roman Public Buildings. Exeter, 67-96

Barr, J. (2011), A Line in the Sand. Britain, France and the Strugle that Shaped the Middle East. Londres.

Bauer, E. (1969), História polémica da Segunda Guerra Mundial, VI. Mem Martins.

Bawer, B. (2010), Enquanto a Europa dormia. Lisboa.

Blanco Freijeiro, A. (1975), El puente de Alcántara en su contexto histórico. Madrid.

Blánquez Pérez, C. (2014), "Bar Sauma versus Dushara: the christianisation of Petra and its sorroundings", in A. Francisco Heredero et alii, (coords.), New Perspective in Late Antiquity in the Eastern Roman Empire. Cambridge, 48-63.

Calvino, I. (2010), As cidades invisiveis. Lisboa.

Christie, A. (2010), Na Síria. Conta-me lá como vives. Lisboa.

Dareggi, G. (2000), La décoration du temple “de Minerve” à Theveste (Tébessa): un exemple de la specificité de la tradition architecturale africaine. Paris.

Davies, N. (2015), Reinos desaparecidos. Lisboa.

Donald, T. L. (1966, 2 2 ed.), Ancient Architecture on Greek and Roman Coins and Medals. Chicago. 
Dunant, Ch. (1971), Le sanctuaire de Baalshamin à Palmyre, III, Les inscriptions. Roma Edwell, P. (2008), Between Rome and Persia: The Middle Euphrates, Mesopotamia and Palmyra under Roman Control. Londres.

Ferguson, J. (1975), Utopias of the Classical World. Londres.

Ferreira de Castro, J. M. (1942), A volta ao mundo. Lisboa.

Fromkin, D. (1989), A Peace to End All Peace. The Fall of the Ottoman Empire and the Creation of the Modern Middle East. Nova Iorque.

Gollard, P. e Vicari, J. (1969), Le sanctuaire de Baalshamin à Palmyre, I-II, Topographie et architecture. Roma.

Grabar A. (2002, 2ª ed.), La iconoclastia bizantina. Madrid.

Grant, M. (1996), Art in the Roman Empire. Londres.

Gros, P. (1996), L'architecture romaine, 1, Les monuments publics. Paris.

Harmanşah, Ö. (2015), "ISIS. Heritage and the Spectacle of Destruction in the Global Media", Near Eastern Archaeology 78 (3): 170-177.

Hayman, R. (2015), The Tudor Reformation. Oxford.

Huxley, A. (s/d), Regresso ao admirável mundo novo. Lisboa.

Ibn Khaldun (1958), The Muqaddimah. An Introduction to History, 1-3 (trad. F. Rosenthal). Princeton.

Kalisky, R. (1968), Le monde arabe, 2. Verviers.

Kennedy, D. e Riley, D. (2004), Rome's Desert Frontier. Londres.

Lewin, A. (2011), "The New Frontier of Late Antiquity in the Near East. From Diocletian to Justinian", in O. Hekster e T. Kaizer (eds.), Frontiers in the Roman World. Leida, 233-264.

Lukitz, L. (2006), A Quest in the Middle East. Gertrude Bell and the Making of Modern Iraq. Nova Iorque.

MacMullen, R. (1992, 2a ed.), Ennemies of Roman Order: Treason, Unrest and Alienation in the Empire. Londres.

Mantas, V. G. (2003), "Penélope e Ulisses na Lusitânia”, in F. de Oliveira (ed.), Penélope e Ulisses. Coimbra, 145-166.

Mantas, V. G. (2008), “O valor da ruína”, Biblos 6: 147-192.

Mantas, V. G. (2012), “O legado histórico romano e a crise do Ocidente contemporâneo", Biblos 10: 47-73.

Millar, F. (1993), The Roman Near East 31 B.C. - A.D. 337. Cambridge.

Moatti, C. (1989), À la recherche de la Rome antique. Paris.

Morató, C. (2006), Las damas de Oriente. Grandes viajeras por los países árabes. Barcelona. 
Moscati, S. (1963), L’Orient avant les Grecs. Paris.

Parlasca, K. (1976), "Probleme palmirenische Grabreliefs. Chronologie und Interpretation", in E. Frézouls (ed.), Palmyra: Billan et Perspectives. Estrasburgo: 139-151.

Picard, G.- Ch. (1959), La civilisation de l'Afrique du Nord romaine. Paris.

Picard, G.- Ch. (1965), Empire romain. Friburgo.

Pirenne, H. (1939), Mohammed and Charlemagne. Londres,

Prickartz, R. (1995), “Phillipe l'Arabe (244-249), Civilis Princeps”, AC 64: 129-153.

Roddaz, J. M. (2000), “L'héritage”, in F. Hinard (ed.), Histoire Romaine, I. Paris: 825-912.

Sahner, Ch. (2014), Among the Ruins: Syria Past and Present. Nova Iorque.

Robertson, D. S. (1992, $2^{\mathrm{a}}$ ed.), Greek and Roman Architecture. Cambridge.

Romain, P. (2015), "Il faut sauver Palmyre", Archéologia 533: 4-7.

Satia, P. (2008), Spies in Arabia. The Great War and the Cultural Foundations of Britain's Covert Empire in the Middle East. Oxford.

Schwartz, J. S. (1976), "Palmyre et l'oposition à Rome en Égypte", in E. Frézouls (ed.), Palmyre. Billan et perspectives. Estrasburgo: 134-151.

Sidebotham, S. (2012), Berenike and the Ancient Maritime Spice Route. Berkeley - Los Angeles.

Silver, M. (2015), "Remote Sense, Landscape and Archaeology tracing ancient Tracks and Roads between Palmyra and the Eufrates on Syria", Annals of the Photogrammetry, Remote Sense and Spatial Information Sciences II 5/ W3: 279-285

Smith II, A. (2013), Roman Palmyra: Identity, Community and State Formation. Oxford.

Sournia, J. Ch. e Sournia, M. (1966), L'Orient des premiers chrétiens. Paris.

Southern, P. (2008), Empress Zenobia: Palmyra's Rebel Queen. Londres - Nova Iorque.

Stoneman, R. (1994), Palmyra and its Empire. Zenobia's Revolt Against Rome. Ann Arbor.

Teixidor, J. (1979), The Pantheon of Palmyra. Leida.

Tozza, M. (2015), “Dionisismo y cultoprehelénico a la Madre”, Humanitas 67: 59-81.

Van Berchem, D. (1976) "Le plan de Palmyre", in E. Frézouls (ed.), Palmyre. Billan et perspectives. Estrasburgo, 165-173.

Volney, Conde de (s/d) [1960], As ruínas de Palmira. Meditação acerca da destruição dos impérios. Lisboa. 
Volney, M. (1791), Les ruines, ou méditation sur les révolutions des empires. Paris. Wheeler, M. (1964), Roman Art and Architecture. Londres

Wiegand, Th. (1922-1923), Baalbek, I-II. Berlim-Lípsia.

Winstone, H. (2004), Gertrude Bell: A Biography. Gloucester.

Young, G. (2003), Rome's Eastern Trade: International Commerce and Imperial Policy $31 B C-A D$ 305. Londres. 